\title{
No more dithering on e-health: let's keep patients safe instead
}

Previously published at www.cmaj.ca

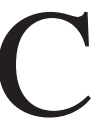
anada has invested $\$ 1.6$ billion - and counting — in federal funds to develop integrated electronic health records that will, among other things, help provide seamless and timely care to a growing population with complex needs. So what have we received for that massive investment? Not nearly enough, according to two recent reports.

In 2009, the use of electronic health records by Canadian general practitioners was 37\%, up from 14\% in 2000, according to the Commonwealth Fund. Compare that with 97\% (from $52 \%$ ) in New Zealand and 95\% (from 25\%) in Australia.

Indeed, in the Commonwealth Fund's 2009 survey of primary care physicians in 11 countries, ${ }^{1}$ Canada ranks in the lower half on every measure on the survey; most often, our rank is at or near the bottom.

For example, only $27 \%$ of Canadian general practitioners are able to prescribe electronically (last), $41 \%$ have electronic access to laboratory test results (second to last) and 37\% can generate a list of patients with a particular diagnosis (second to last). In several countries, more than $90 \%$ have these three basic capabilities. Even more telling, only $14 \%$ of Canadian general practitioners report having 9 or more of 14 functions deemed to signal advanced electronic capability. That's the bottom of the pack, distantly trailing New Zealand (92\%), Australia (91\%) and the United Kingdom (89\%).

Then consider a November 2009 report by the federal auditor general on Canada Health Infoway, the organization created to build a pan-Canadian infrastructure for electronic health records. The report noted one of Infoway's goals: "By 2010, 50 per cent of Canadians and, by 2016, 100 per cent will have their electronic health record available to their authorized health care professionals." However, the report adds, "Infoway officials told us that having electronic medical records 'available' does not necessarily mean that they are being used or that they are compatible across the country."

So after billions of dollars and nearly a decade of work by Infoway and the provinces, Canada is well back of the electronic records pack. In five years, we can look forward to "available" electronic health records that show no signs of being implemented in a reasonable segment of the population at large - even though evidence suggests that one of the simplest functions, e-prescribing, can save lives. ${ }^{2}$

Our laggard position is certainly not a question of software design or lack or access to user-friendly technologies. There is no shortage of vendors that can provide outstanding products, service contracts and support. The platform being created by Infoway will ensure that the products will be compatible.

Other countries combined strong vision and leadership with financial and technical support and inducements strong enough to encourage universal (and fast) adoption. New Zealand, for example, offered financial and technical support for primary care physicians. In return, physicians were required to submit all of their bills electronically.
In Canada, we have relied solely on weak inducements to "pull" providers into adopting electronic records. Further inducements will invariably fail to achieve $100 \%$ adoption. It's time to change our approach.

Starting with vision, we would do well to adopt CMA President Anne Doig's goal to have every physician using electronic health records by 2011. We need to apply our efforts in making electronic records easy to use and universally accessible at the point of care.

For leadership, Infoway's mandate should shift from its sole focus on developing a technical infrastructure to a program run jointly by the provincial and federal governments aimed at implementation and use. Physicians should use their political leverage to push for an implementation strategy that will meet their concerns and put them on the information highway.

Our governments should dedicate (or reallocate) funds to help physicians implement and troubleshoot software concerns. Much stronger positive inducements and ongoing support will be required to dramatically increase the number of physicians and primary care professionals who adopt electronic records.

Given the ongoing threats to patient safety, it is critical that our medical and political leaders set timely targets for universal adoption of electronic health records for all health professionals, especially in primary care. Unfortunately, mandating the use of electronic health records may be the only way to avoid long delays.

Our slow progress on electronic health records should act as a call to action. An electronic health record system with access for everyone - family physicians, consultants, pharmacists, hospitals, managers and researchers - will save lives and improve health outcomes. Canadians deserve nothing less.

\section{Kimberlyn McGrail PhD MPH \\ Michael Law PhD MSc \\ Centre for Health Services and Policy Research \\ University of British Columbia \\ Vancouver, BC \\ Paul C. Hébert MD MHSc \\ Editor-in-Chief \\ CMAJ}

With the editorial advisory team: Ken Flegel MDCM MSc,

Noni MacDonald MD MSc, Matthew B. Stanbrook MD PhD and Joan Ramsay BA

Competing interests: See www.cmaj.ca/misc/edboard.shtml for editorial advisory team statements. None declared for Kimberlyn McGrail and Michael Law.

CMAJ 2010. DOI:10.1503/cmaj.092189

\section{REFERENCES}

1. Schoen C, Osborn R, Doty MM, et al. A survey of primary care physicians in eleven countries, 2009: perspectives on care, costs, and experiences. Health Aff 2009;28:W1171-83.

2. Morgan MW. In pursuit of a safe Canadian healthcare system. Healthc Pap 2004; 5:10-26.

All editorial matter in CMAJ represents the opinions of the authors and not necessarily those of the Canadian Medical Association. 